\title{
U.S. Geological Survey (USGS) Western Region: Santa Barbara Channel Coastal and Ocean Science
}

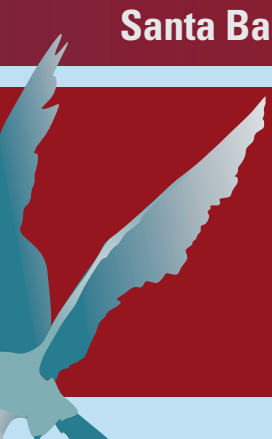

USGS coastal and ocean science in the Western United States and the Pacific integrates scientific expertise in geology, water resources, biology, and geography. Operating from 10 major science centers in the Western Region, the USGS is addressing a broad geographic and thematic range of important coastal and marine issues. In California, the Santa Barbara Channel represents one area of focus.

\section{Santa Barbara Channe]}

The Santa Barbara Channel area extends from the steep Santa Ynez Mountains on the north to the Channel Islands and adjacent continental shelf on the south and from Point Conception east to the Hueneme submarine canyon. This dynamic landscape, characterized by diverse ecosystems and both urban and rural populations, faces increasing environmental stress due to development, climate change, and natural hazards. The USGS has a long history of work in this area, providing information on a range of coastal-zone-management issues to local, State, and Federal stakeholders. Agencies of the U.S. Department of Interior have specific land- and natural-resource-management responsibilities in the Santa Barbara Channel associated with

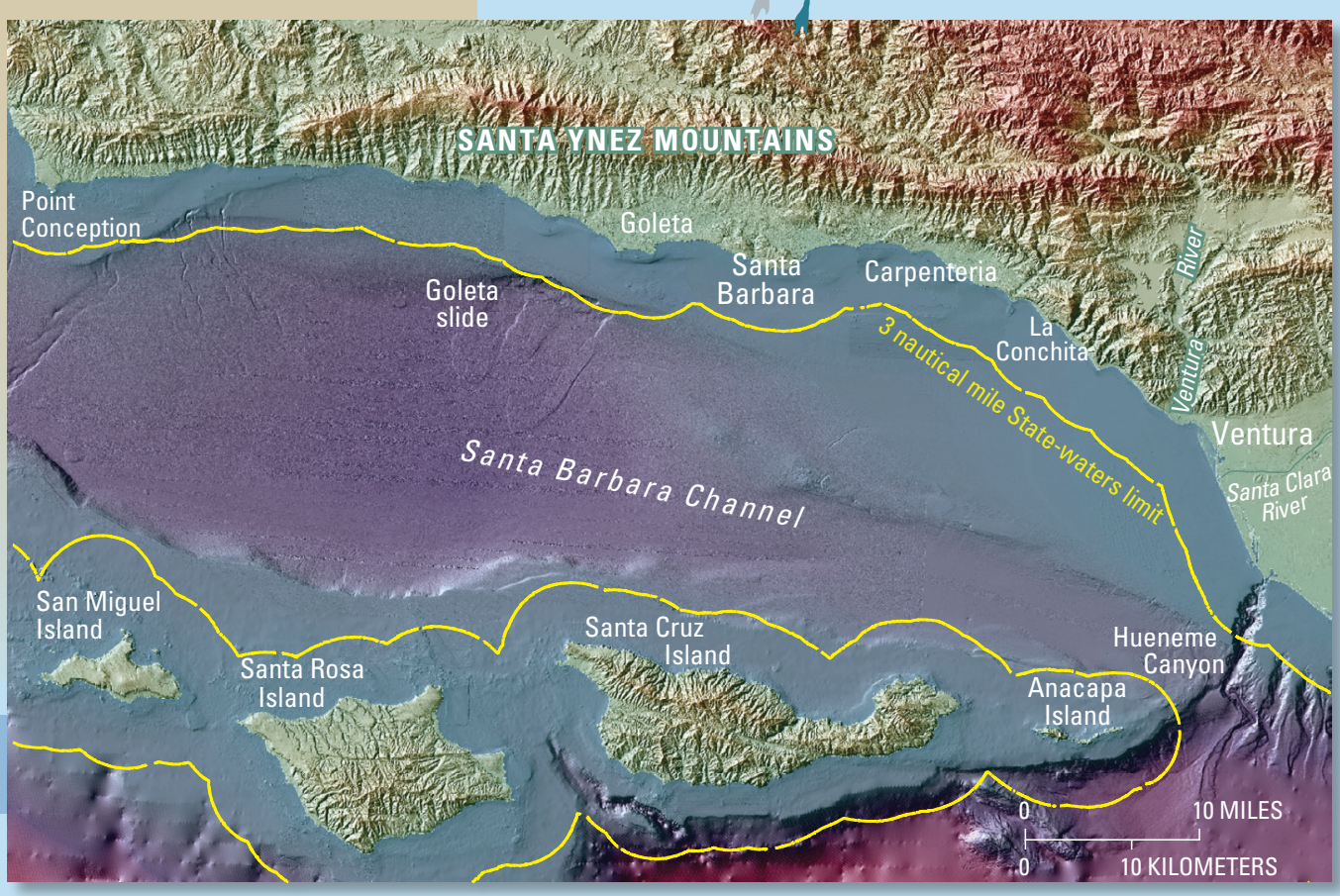

New high-resolution, shaded-relief seafloor map of Santa Barbara Channel.

the Channel Islands National Park (National Park Service), petroleum production and infrastructure in Federal waters (Minerals Management Service), and endangered species recovery (Fish and Wildlife Service). The Santa Barbara Channel is also the location of the Channel Islands National Marine Sanctuary and other important marine protected areas.

\section{New USGS Mapping}

The USGS is conducting a seafloor, habitat, and geologic mapping effort in the Santa Barbara Channel area in cooperation with the California Coastal Conservancy, the California State Waters Mapping Program, the California Geological Survey, the Minerals Management Service (MMS), Monterey Bay Aquarium Research Institute (MBARI), NOAA National Marine Sanctuaries, and numerous local stakeholders. Mapping supports an important action item of the West Coast Governors' Agreement on Ocean Health and will result in products that address many coastal-zone-management issues, including fisheries management, designation of marine protected areas, sediment management and coastal erosion, sediment and contaminant movement, earthquake and tsunami hazards, impacts of dam removal, documentation of natural oil and gas seeps, and evaluation of sites for offshore infrastructure. 


\section{Natural Hazards}

Both onshore and offshore landscapes in the Santa Barbara Channel area are geologically active, variably characterized by rapid uplift or subsidence, cut by active faults capable of generating powerful earthquakes, and subject to rapid erosion, including large-scale landsliding.

\section{Earthquakes}

Active faults in the Santa Barbara Channel can generate earthquakes as powerful as magnitude 7 or greater. The USGS is documenting the locations, geometry, and slip rates of all the major earthquake faults in this area, information essential for seismichazard assessment and mitigation.

\section{Landslides}

USGS mapping and age dating of the Goleta slide and other offshore landslides provide information for evaluating potential sources of local tsunamis that could affect the Santa Barbara Channel coast. Onshore investigations and mapping document the

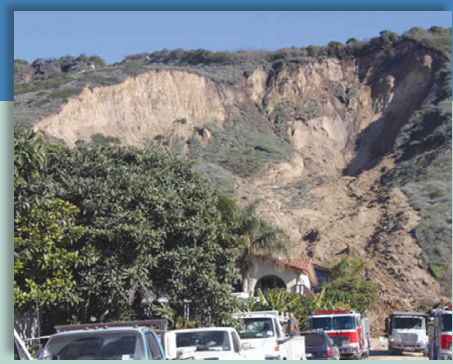

View of the January 2005 landslide that struck the community of La Conchita in coastal Ventura County, killing 10 people and destroying or seriously damaging 36 houses.

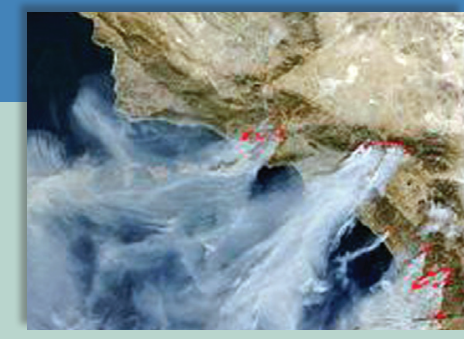

Satellite view of the 2003 wildfires in southern California. The Santa Barbara Channel coast and Channel Islands are visible through the smoke near the center of the image. impacts of winter storms, wildfires, and land use on slope failures and identify landslide-prone coastal terrane.

\section{Wildfires}

The USGS continues to document the influence of increasingly common wildfires on landscapes and ecosystems in coastal watersheds. Sampling and analysis of sediment and fire-related contaminants coming out of the Santa Clara and Ventura Rivers after the 2003 wildfires has provided important information about the potential impact of fires on the sensitive nearshore environment of the Santa Barbara Channel.

\section{Climate Variability and Change}

Climate change will affect humans and ecosystems in the Santa Barbara Channel.

Understanding past natural changes is key to forecasting the effects of climate change.

\section{Sea-Level Rise, Coastal Erosion, and Inundation}

In the coming decades, sea-level rise will likely result in increased coastal erosion and beach loss, more frequent coastal flooding from winter storms, wetland loss and degradation, and associated negative impacts on nearshore marine and adjacent terrestrial ecosystems. The USGS has established a baseline coastal bathymetric grid and has documented coastal oceanographic processes and sediment transport from Goleta to Ventura for use in modeling and forecasting future coastal change and inundation from massive winter storms and sea-level rise. Results from these efforts are essential for planning and minimizing risk to coastal communities.

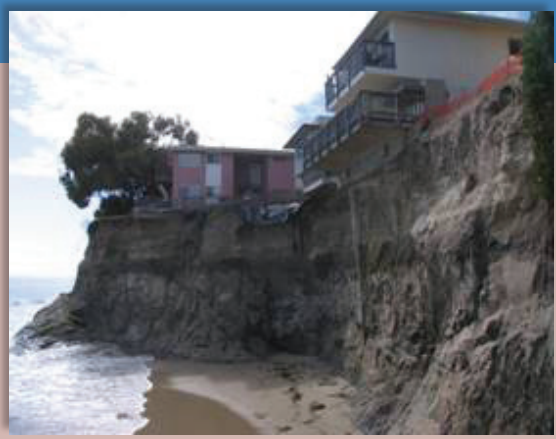

Severe coastal erosion in Isla Vista, adjacent to the University of California, Santa Barbara.

\section{Forecasting the Ecosystem Impacts of Climate Change}

Potential changes in ocean temperature, upwelling, and ocean currents are likely to affect nutrient supply to marine food webs composed of diverse and abundant phytoplankton, zooplankton, fishes, seabirds, and marine mammals. Seabirds are excellent indicators of changes in marine ecosystems and ecosystem health. They are abundant and have

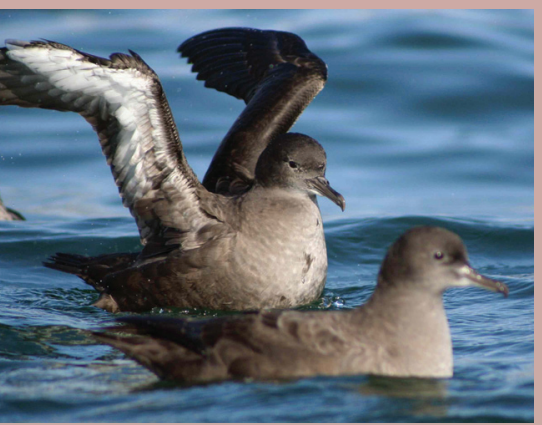

Sooty Shearwaters are the most abundant seabird in California waters during the spring and summer and are an excellent "sentinel species" for tracking variability in the biologic productivity of coastal ocean areas. diversified to use a variety of niches within marine ecosystems, and their health and behavior provide crucial information about lower levels in the food chain. USGS studies of "sentinel species," such as the Cassin's Auklet and Sooty Shearwater, focus on the seabird's use of nearshore habitat, which is affected by climatedriven variability in the abundance of their prey. Studies are designed to measure breeding success, diet, habitat connections, and population trends, and to support restoration of important seabird colonies in the Channel Islands National Park.

\section{Paleoclimate Studies}

The USGS is studying the effects of climate change and variability on geologically recent landscape evolution in Channel Islands National Park. Most sand dunes that mantle the Channel Islands originated from the now-submerged shelves of the islands, which were exposed during glacial periods when sea level was about 300 feet lower than at present. High sea-level stands between glacial periods are recorded by emergent, geologically uplifted marine terraces containing fossil mollusks with shells that record a

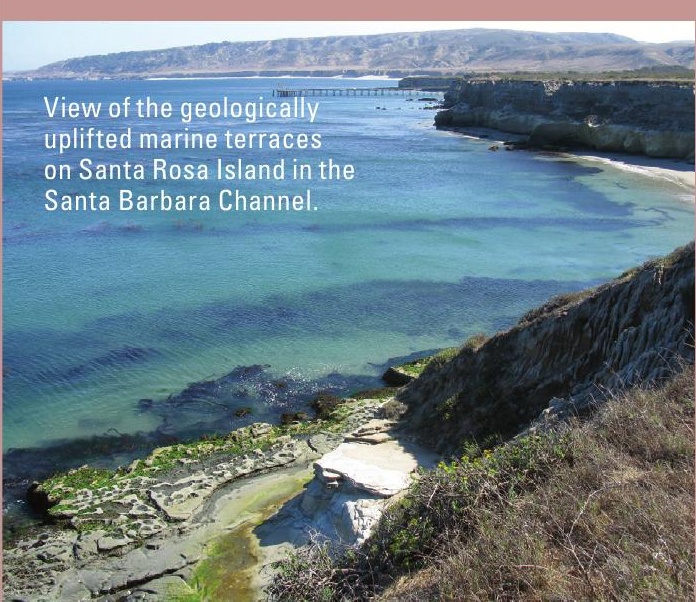
much warmer period about 120,000 years ago-a period that may be similar to those resulting from future climate change. 


\section{Understanding Ecosystems}

It is increasingly important to understand the ecological, economic, and cultural value of marine ecosystems. For example, California's Marine Life Protection Act requires that the best available scientific information be used to evaluate and design the State's marine protected areas to be effective in ensuring the future of crucial marine ecosystems. It is important to understand how potential changes in ocean temperature, upwelling, and ocean currents will likely affect marine food webs, from the phytoplankton communities at their bases to upper-level predators such as fishes, seabirds, and marine mammals.

\section{Ecosystem Responses to Fishing in the Channel Islands}

USGS analyses of long-term National Park Service data on reef communities from the Channel Islands have shown that fishing can have important indirect effects on ecosystems. For example, lobster overfishing in unprotected areas has led to increased sea urchin populations, resulting in overgrazed kelp forests that have weakened resistance to storms. Recovering lobster populations prey on sea urchins and thus can aid the return of kelp.

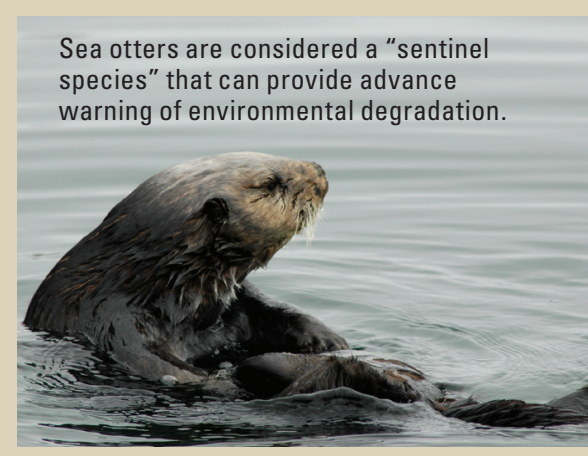

\section{Sea Otter Health}

USGS work shows that sea otters living in the Santa Barbara Channel risk higher exposure to disease-causing parasites as a consequence of the food they eat and where they feed. Diet specialization, depleted food resources, and high rates of infectious disease may be acting together to limit the recovery of sea otters, considered a "sentinel species" that can provide advance warning of environmental degradation.

\section{Endangered Snowy Plover Recovery}

The western Snowy Plover breeding season coincides with the busy beach season in the Santa Barbara Channel. A comparison of public beaches on the mainland with remote beaches on the Channel Islands shows that humans frequently disturb Snowy Plovers. By observing the distribution and behavior of humans and plovers, USGS scientists and their cooperators developed a management model to maximize protection of plovers and minimize inconvenience to people. After establishing a

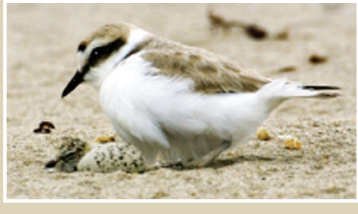

The endangered Snowy Plover. small protected area at the core of the Snowy Plover roost, disturbance was reduced, plover numbers increased, and plovers bred successfully for the first time in three decades.

\section{Parasites in Food Webs}

Ecosystem-based management requires an understanding of ecological networks composed of food webs and habitat dependencies. USGS work in Carpinteria salt marsh shows that understanding of infectious organisms in food webs is inadequate. Parasites dominate food web links, can serve as food sources, and constitute more biomass than do top predators. This work is now expanding to other habitats in the Santa Barbara Channel.

\section{Energy and Minerals}

\section{Sand and Beaches}

In the face of coastal erosion, sand and sediment are increasingly regarded as valuable mineral commodities. USGS work on coastal processes is providing detailed information on how sand along the Santa Barbara Channel coastline is moving offshore and onshore as well as eastward along the coast. USGS offshore mapping also shows the location and thickness of offshore sand deposits. These data are being used to develop models of sediment transport and coastal evolution that will help guide many coastal-zone-management efforts, such as beach nourishment.

\section{Submarine Canyons}

Submarine canyons are the conduits for moving sediment from the coast down to the deep sea. Hueneme Canyon, located at the east end of the Santa Barbara Channel (see map) extends almost to the shoreline and intercepts sand moving alongshore. The USGS has deployed oceanographic instruments in the canyon and on its margins to better understand regional sediment budgets, sediment transport into and down the canyon, and canyon stability. It is especially important to understand how the canyon head might change given projected sealevel rise and possible changes in human practices (for example, harbor dredging) in the adjacent coastal zone.

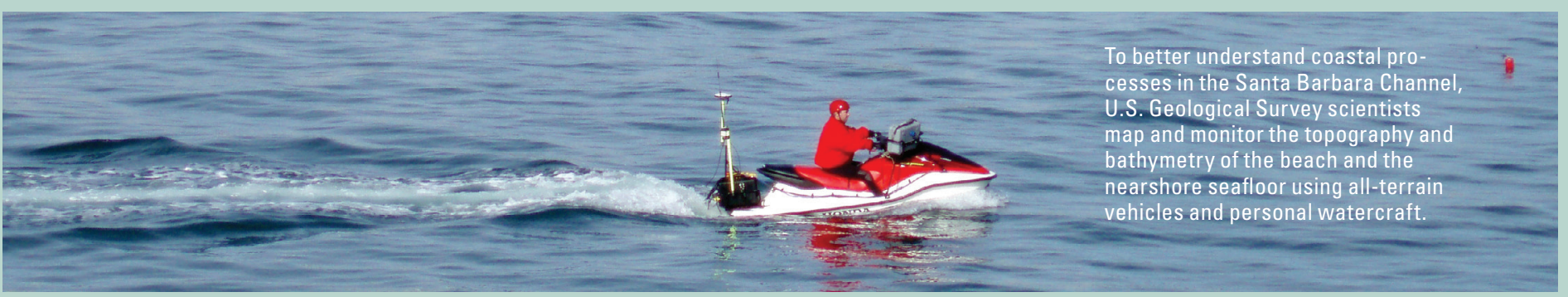




\section{Natural Oil and Gas Seepages}

Tar and oil residues are common on California beaches, especially in the Santa Barbara Channel, where natural oil seeps abound on the seafloor. The USGS is working with the MMS and the University of California, Santa Barbara (UCSB) to document the locations of seeps, geochemically fingerprint oil from the seeps, measure seepage rates, and predict transport pathways of oil from seep sources to the coastline. The geochemical database is being used statewide to understand the sources, movement, and fate of oil derived from natural seeps, and to distinguish these oils from man-made spills.

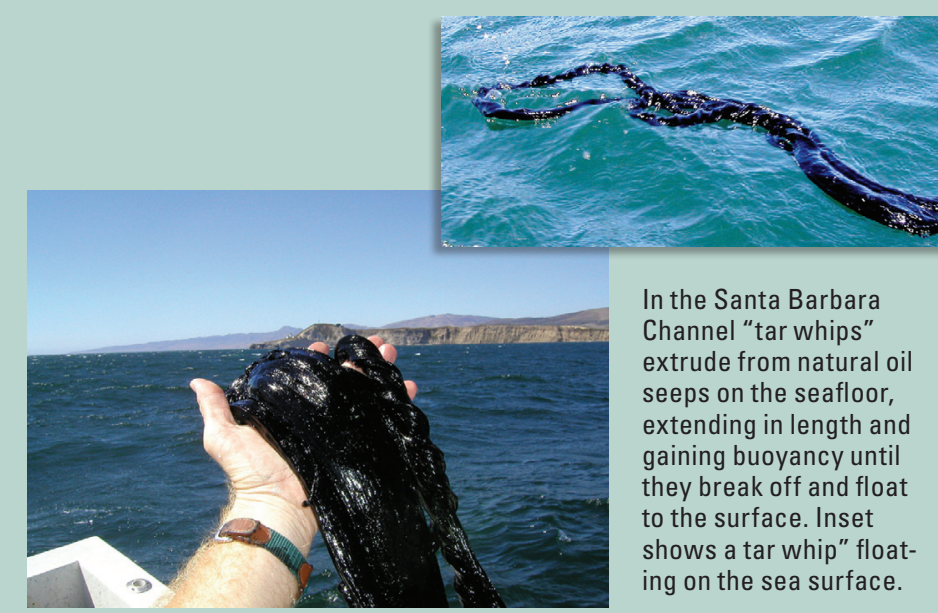

\section{Water Management and Resources and Public Health}

\section{Beach Health}

Beaches are popular with humans and provide crucial animal habitat, but beach closures and warnings due to high bacterial levels are becoming increasingly common. To address this problem in Santa Barbara, the USGS used genetic, chemical, and optical techniques to distinguish between different sources of bacterial contamination, such as storm drains, leaking sewers, discharge from urban streams, and the resident shorebird population. Determining the source of such pollution is essential for defining effective mitigation strategies.

\section{Submarine Groundwater Discharge}

Given the steep topography along the south flank of the Santa Ynez Mountains, diffuse submarine groundwater discharge may provide nearshore coastal waters with a sustained influx of nutrients, bacteria, and trace elements that can contain pollutants and may play a significant role in the development of algal blooms. The USGS has deployed a suite of seepage meters, electrical-resistivity sen-

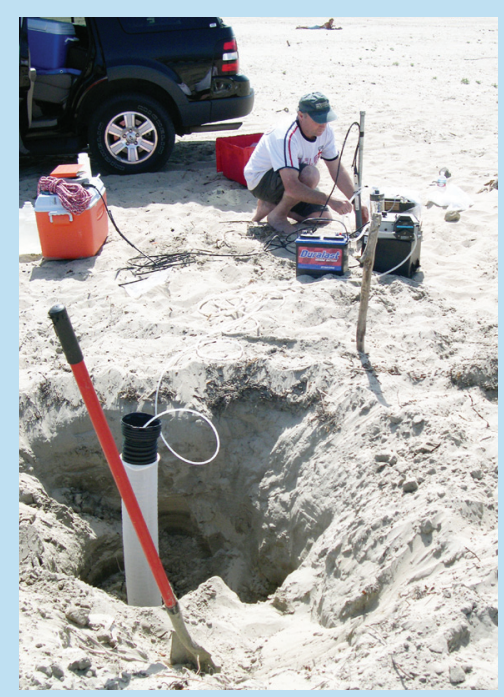

Sampling for groundwater nutrients and submarine groundwater tracers from a temporary piezometer (small water well) on Santa Barbara's West Beach.

\section{Coastal Watersheds}

Winter storms in coastal watersheds move a large amount of water, sediment, and contaminants into the coastal zone. The USGS is studying the impacts of such storms and the processes through which sediment is dispersed from the Santa Clara and Ventura Rivers into the marine environment of the Santa Barbara Channel. The USGS also plans to study the effects on the coast and watershed of removal of the Matilija Dam on the Ventura River (expected in the next few years) to develop a framework for science-based forecasts of damremoval effects in other areas.

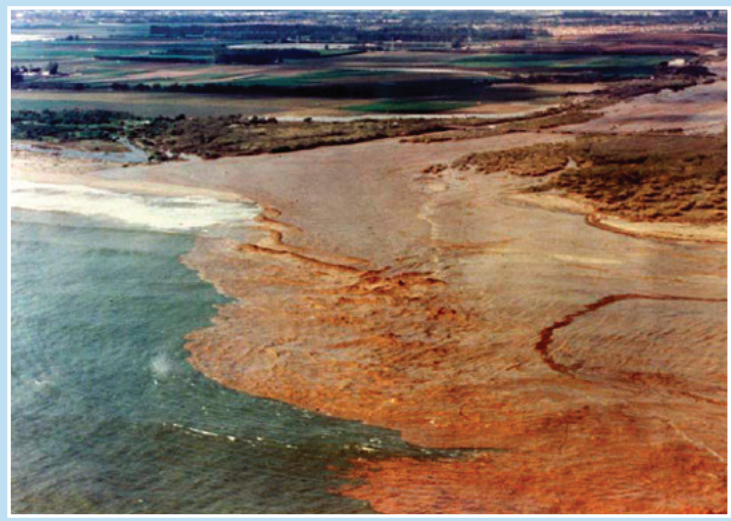

Brown sediment plume at the mouth of the Santa Clara River following a large storm event. sors, and such geochemical tracers as radon and radium isotopes to better understand this submarine groundwater discharge and its environmental significance.
More information on USGS activities in the Santa Barbara Channel can be found at http:// walrus.wr.usgs.gov/research/sbchannel.html. The USGS is the Nation's largest water, earth, and biological science and civilian mapping agency. USGS serves the Nation by providing reliable scientific information to describe and understand the Earth; to minimize loss of life and property from natural disasters; to manage water, biological, energy, and mineral resources; and to enhance and to protect our quality of life.

\section{For more information contact:}

Samuel Y. Johnson

USGS Pacific Science Center 400 Natural Bridges Drive Santa Cruz, CA 95060 (831) 427-4746 sjohnson@usgs.gov

This Fact Sheet and any updates to it are available on line at: http://pubs.usgs.gov/fs/2009/3077/ 